\title{
Genetics studies on inheritance of stripe rust resistance in wheat.
}

\author{
Kamal, Nagwa, M. A.; El-Garhy,Hoda ${ }^{1}$, A. S.; Gad ${ }^{2}$, K. I.; Ibrahim³ $^{3}$ S. D.; Sherif ${ }^{1}$, H. S. A. and \\ Bekhit $^{1}$, M. M. M. \\ ${ }^{1}$ Department of Genetics and genetic engineering, Faculty of Agriculture, University of Benha, Egypt. \\ ${ }^{2}$ Department of Wheat crops, Plant crops Research Institute, Agriculture Research Center, Giza, Egypt. \\ ${ }^{3}$ Agricultural Genetic Engineering Research Institute (AGERI), Agriculture Research Center, Giza, Egypt \\ Corresponding author: makhlouf.bakhit@fagr.bu.edu.eg
}

\begin{abstract}
This work was carried out to study the response of four Egyptian bread wheat cultivars i.e Giza 168, Giza 171, Sids 12 and Sids 13, to yellow rust disease and its effect on grain yield components under field condition at Nobaria Agriculture Research Station, during two growing seasons , (2015/16 - 2016/17). Results showed that there was a significant difference among the tested cultivars from the most of the studied yield parameters. Giza 171 had the highest significant values of days of heading plant height, grain yield, number of grain/spike and 1000 grain yield in the two seasons. On the other hand according to disease assessment Sids 12 had the highest significant values of final rust severity (FRS), rate of disease increase (r-value) and area under disease progress curves (AUDPC) in the two seasons. Inter-simple sequence repeat (ISSR) marker was used to measure the genetic diversity between one Stripe rust resistant wheat cultivar (YR7), the four local cultivated varieties and the F1 cross progeny. Ten ISSR primers were used, a total of 109 bands were amplified, among which 41 (37\%) bands were polymorphic. The polymorphic bands amplified by each primer ranged from 2 to 8 , with an average of 4.1. The genetic similarity ranged from $88 \%$ to $96 \%$.
\end{abstract}

Key words: Strip rust, wheat, ISSR, PCR, disease.

\section{Introduction}

Egypt now is known as the world's largest wheat importer country. According to the Food and Agriculture Organization of the United Nations (FAO, 2016), the total cultivated area of wheat in Egypt is 1,33 million hectares with a total production of 9 million tons. The total wheat consumption in Egypt is 19 million tons, this wide gap between consumption and actual production forces the country to import 10 million tons to close this gap. Management practices play an important role in determining the yield and are essential to enhance wheat production and reduce importing. Wheat is grown in a wide range of environments that affect overall performance, particularly grain yield. Climatic factors. Over which producers have little control (such as precipitation, temperature, day length), soil types, and management practices (such as fertilizer, herbicides, fungicides, irrigation, time of sowing and rusts diseases (such as leaf rust, stem rust and strip (yellow) rust. Wheat is a host for three rust fungi Puccinia graminis, Puccinia triticina and Puccinia striiformis causing the diseases stem rust, leaf rust and yellow rust, respectively In Egypt, yellow rust is a sporadic disease because it appears in same year in near and Middle East regions. However, starting from 1990s, it became common due to its continuous appearance (Abu El-Naga et al., 2001), (Roelfs and Bushnell 1985 that consider the most important diseases on wheat (Johnson 1992; Singh et al., 2004 and Pratt and Gordon 2006).

Inter simple sequence repeat (ISSR) markers (Zeitkiewicz et al. 1994) have emerged as an alternative system with the reliability and advantages of microsatellites (SSR) along with the broad taxonomic applicability of RAPDs. The technique involves amplification of genomic segments flanked by inversely oriented closely spaced microsatellite sequences by a single primer based on SSRs anchored $5^{\prime}$ or $3^{\prime}$ with $2-4$ purine or pyramidine residues. They are mostly dominant markers. Number of primers can be synthesized for various combinations of di-, tri-, tetraand penta- nucleotides [e.g. $33=27,44=256$ ] with a few based anchor. ISSRs have been used for detection of polymorphism (Nagaoka and Ogihara,1997) and in genetic mapping of wheat (Kojima et al, 1998). ISSRs have also been used to identify markers associated with seed size (AmmiRaju, et al, 2001) and yellow berry tolerance in wheat in our laboratory. Al-kaab et al., (2016) reported the using of 37 ISSR to study the degree of genetic diversity, Polymorphism information content (PIC) and resolving power (RP) were estimated. They reported that, all the studied molecular markers were informative and showed good ability to classify and distinguish 16 wheat varieties. Total number of polymorphic bands is 134 for ISSR. Goyal et al., (2015) used a total of 11 ISSR primers, 95 amplified bands were obtained of which 46 were polymorphic. The average number of polymorphic bands was 4.18 ISSRs.

\section{Materials and Methods}

The impact of genetics studies on inheritance of stripe rust disease resistance in bread wheat cultivars i.e Giza 168, Giza 171Sids 12 and Sids 13 (Table 1) were studied at Nubaria Agriculture Research Station 
in 2015/16 and 2016/17 growing seasons. The field was prepared with standard production practices, such as land preparation, fertilizer application, herbicide application. Each-year the experiment was conducted as a randomized complete block design with five replications. and seed rate (four seeding rates were 200, 250, 300 and350 seeds/m2).

Table 1. Name, pedigree, and year of release of four wheat genotypes.

\begin{tabular}{cllr}
\hline No. Genotypes & Pedigree & $\begin{array}{r}\text { Year of } \\
\text { Release }\end{array}$ \\
\hline 1 & Giza.1 & MAL / BUC // SERI CM93046-8M-0Y-OM-2Y-0P & 1995 \\
& 68 & & 2013 \\
\hline 2 & Giza.1 & SAKHA 93 / GEMMEIZA 9S.6-1GZ-4GZ-1GZ-2GZ-0S & 2007 \\
\hline 3 & Sids.12 & $\begin{array}{l}\text { BUC//7C/ALD/5/MAYA74/ON//1160.147/3/BB/GLL/4/CHAT"S"/6/MAYA/VUL//CMH74A } \\
\text {.630/4*SXSD7096-4SD-1SD-1SD-0SD }\end{array}$ \\
\hline 4 & Sids.13 & $\begin{array}{l}\text { KAUZ'S" / TSI / SNP"S" ICW 94-0375-4AP-2AP-030AP-0APS-3AP-0APS-050AP- } \\
\text { 0AP-0SD }\end{array}$ & 2010 \\
\hline
\end{tabular}

\section{Measurements}

Number of yield-related measurements at the harvest time were recorded including Days of heading, Days of maturity, Biological yield $(\mathrm{Kg})$, plant height (cm), Grain Yield (kg), N. of Spikes/M² number of grains per spike and 1000 grains weight $(\mathrm{g})$. disease assessments were assessed through host response, and different components of disease incidence and their development and estimated as: final rust severity (FRS) was recorded as outlined by Das et al., 1993 as the disease severity (\%), when the highly susceptible check variety was severely rusted and the disease rate reached the highest and final level of rust severity.Rate of disease increase (r-value) as a function of time, was also estimated to determine the ability of the tested genotype to affect the development of rust infection under field conditions. It was calculated from the different rust scores as a severity of rust infection at the time of rust pastules appearance and every seven days there after. Rate of rust increase (r-value) was estimated using the following formula adopted by (Van Der Plank, 1963):

$$
\text { r-value }=\frac{1}{t_{2}-t_{1}}\left(\log _{\mathrm{e}} \frac{\mathrm{X}_{2}}{1-\mathrm{X}_{2}}-10 \mathrm{~g}\right.
$$

\section{$\mathrm{X}_{1}$}

$$
\text { )(Van der plank, 1963) }
$$

Where:

$\mathrm{X}_{1}=$ the proportion of the susceptible infected tissue

(disease severity) at date $\mathrm{t} 1$

$\mathrm{X}_{2}=$ the proportion of the susceptible infected tissue

(disease severity) at date $\mathrm{t} 2$

$t_{2}-t_{1}=$ the interval in days between these dates

Area under disease progress curves (AUDPC), was estimated to compare different responses of the tested genotypes using the following equation adopted by Pandey et al. (1989)

$A U D P C=D\left[1 / 2\left(Y_{1}+Y_{k}\right)+Y_{2}+Y_{3}+\ldots . . . . Y_{k}-1\right]$

Where:

$\mathrm{D}=$ days between reading

$\mathrm{Y}_{1}=$ first disease recording

$\mathrm{Y}_{\mathrm{k}}=$ last disease recording

\section{Statistical analysis:}

Data collected for the two seasons were subjected to analysis of variance and means of treatment effects and also determined. Least significant differences (L.S.D at 5\%). Which were compared using Duncan's Multiple Range Test (Duncan,1955). All statistical analysis was performed using analysis of variance technique by "WASP Web Agri. Stat. Package.

DNA extraction, purification and quantification:

Genomic DNA was extracted from young leaves of each cultivar using DNeasy Plant Mini Kit (QIAGEN, Hilden, Germany). The quantity and quality of the extracted DNA were determined using spectrophotometric measurement of UV absorbance at $260 \mathrm{~nm}$ and $280 \mathrm{~nm}$ in a Thermo Scientific NanoDrop $2000^{\mathrm{TM}}$ spectrophotometer.

ISSR (Inter simple sequence repeat) technique:

ISSR-PCR reactions were conducted using ten anchored primers which were synthesized by Eurofins, Germany. The primer names and sequences are shown in Table (4). The reaction conditions were optimized and the following reagents were mixed in a final volume of $25 \mu \mathrm{l}$ : $1 \mathrm{X}$ of green GoTaq ${ }^{\circledR}$ Flexi buffer, $1.5 \mathrm{mM}$ of $\mathrm{MgCl}_{2}, 200 \mu \mathrm{M}$ of dNTPs, 25pM of primer, $1 \mathrm{U}$ of $G o T a q \circledR$ Flexi DNA Polymerase (Promega), 25ng of template DNA and up to $25 \mu \mathrm{l}$ distilled H2O. Amplification was carried out in a Gene Amp® PCR System 9700 thermal cycler (Applied 
Biosystems) programmed as follows: $94^{\circ} \mathrm{C} / 5 \mathrm{~min}(1$ cycle); $\left[94^{\circ} \mathrm{C} / 45 \mathrm{sec}, 45^{\circ} \mathrm{C} / 50 \mathrm{sec}, 72^{\circ} \mathrm{C} / 1.5 \mathrm{~min}\right](40$ cycles); $72^{\circ} \mathrm{C} / 7 \mathrm{~min}\left(1\right.$ cycle) and $4^{\circ} \mathrm{C}$ (infinitive). A volume of $10 \mu \mathrm{l}$ of the ISSR-PCR product was resolved using $(1.5 \%)$ agarose gel electrophoresis containing ethidium bromide. A $1 \mathrm{~kb}$ DNA marker (Fermentas) was used as a DNA molecular weight standard. Results were visualized on a UV transilluminator and photographed by Molecular Imager ${ }^{\circledR}$ Gel Doc ${ }^{\mathrm{TM}}$ System with Image $\mathrm{Lab}^{\mathrm{TM}}$ Software, Bio-Rad.

\section{Molecular marker data statistical analysis}

For ISSR analysis, only clear and unambiguous bands were visually scored as either present (1) or absent (0) for all samples and final data sets included both polymorphic and monomorphic bands. Then, a binary statistic matrix was constructed. Dice's similarity matrix coefficients were then calculated between varieties using the unweighted pair group method with arithmetic averages (UPGMA).

\section{Results}

Data presented in Table (2) showed that the wheat cultivars performed differently in first season $(2015 / 16)$ Giza171 recorded the highest significant values of Days of heading (101.6) day, plant height $(113.2) \mathrm{cm}$, grain yield (617) $\mathrm{kg}$, N.of grain /spike (59.4) and 1000- grain (54.12) g. followed by Giza 168 produced the highest significant values for Days of maturity (149) day and Grain Yield (kg) (595) kg, while Sids 12 and Sids 13 had the highest significant values of Grain Yield (kg) and N. of Spikes/M2 (583) $\mathrm{kg}$. And (378.8) spikes $/ \mathrm{m}^{2}$ respectively. However Sids 13 had the lowest values of Plant height $(101.6) \mathrm{cm}$, N. of grain /spike (48) grain/spike and 1000 grain weight (36.13) $\mathrm{g}$ in addition to followed by Giza 168 had low values of Days of heading (98.4) day and N. of grain /spike (46.6) grain/spike then Giza 171 that had low values of Days of maturity (143.2) day and N. of Spikes $/ \mathrm{M}^{2}$ (295) spikes $/ \mathrm{m}^{2}$. On the other hand according to disease assessments Sids 12 was highly susceptible to yellow rust and had the highest values of (FRS) 70S, (r-value) 0.652 and (AUDPC) 865. While Sids 13 was the highly resistance and had low values of (FRS) 5S, (r-value) 0.004 and (AUDPC) 123.

Data presented in Table (3) showed that the cultivars performed differently in second season (2016/17) Giza171 recorded the highest significant values of Days of heading (105.6) day, Days of maturity (157), plant height $(117.8) \mathrm{cm}$, Biological yield (1.96)kg, grain yield (630) kg, N.of grain /spike (54) and 1000- grain (57) g. followed by Giza 168 produced the highest significant values for Days of maturity (157.4) day and Biological yield (1.88)kg, while Sids 13 had the highest significant values of Days of maturity (157) day. However Giza 168 had the lowest values of N.of grain /spike (39) grain/spike, Sids 12 had the lowest values of plant height (106.4)cm and Biological yield (1.59)kg and Sids 13 had low values of Days of heading (101) day and N.of grain /spike (45.2) grain/spike. On the other hand according to disease assessment Sids 12 was highly susceptible to yellow rust and had the highest values of (FRS) 80S, (r-value) 0.846 and (AUNPC) 1425. While Sids 13 was the highly resistance and had low values of (FRS) 10S, (r-value) 0.019 and (AUNPC) 130.

Table 2. The Morphological character Yield components and disease incidence in four Egyptian bred wgeat cultivars at Naboria Agriculture research station during growing season 2015/2016.

\begin{tabular}{|c|c|c|c|c|c|c|c|c|c|c|c|c|}
\hline \multirow[b]{2}{*}{$\begin{array}{c}\text { No } \\
\text { • }\end{array}$} & \multirow[b]{2}{*}{$\begin{array}{c}\text { cultiva } \\
\mathbf{r}\end{array}$} & \multicolumn{3}{|c|}{ Morphological character } & \multirow[b]{2}{*}{$\begin{array}{c}\text { Biologica } \\
\text { l yield } \\
\left(\mathbf{K g} / \mathbf{M}^{2}\right)\end{array}$} & \multirow[b]{2}{*}{$\begin{array}{c}\text { Grain } \\
\text { Yield } \\
\left(\mathrm{kg} / \mathbf{M}^{2}\right. \\
)\end{array}$} & \multicolumn{3}{|c|}{ Yield components } & \multicolumn{3}{|c|}{ disease incidence } \\
\hline & & $\begin{array}{c}\text { Days } \\
\text { of } \\
\text { headin } \\
\text { g }\end{array}$ & $\begin{array}{c}\text { Days of } \\
\text { maturit } \\
y\end{array}$ & $\begin{array}{c}\text { Plant } \\
\text { heigh } \\
\text { t } \\
(\mathrm{cm})\end{array}$ & & & $\begin{array}{c}\text { N.of } \\
\underset{2}{\text { Spikes/M }}\end{array}$ & $\begin{array}{c}\text { N.ofgrai } \\
\text { n /spike }\end{array}$ & $\begin{array}{c}1000 \\
\text { grain } \\
\text { weigh } \\
t\end{array}$ & $\begin{array}{l}1 \\
\text { FRS }\end{array}$ & $\begin{array}{c}2 \\
\mathrm{r}- \\
\text { value }\end{array}$ & $\begin{array}{c}3 \\
\text { AUDP } \\
\mathbf{C}\end{array}$ \\
\hline 1 & $\begin{array}{c}\text { Giza } \\
168 \\
\end{array}$ & $98.4 \mathrm{c}$ & $149.0 \mathrm{a}$ & $\begin{array}{c}110.0 \\
b\end{array}$ & 2.040 & $595.0 \mathrm{a}$ & $312.0 \mathrm{~b}$ & $46.6 \mathrm{c}$ & $\begin{array}{c}45.87 \\
b\end{array}$ & $20 \mathrm{~S}$ & $\begin{array}{c}0.02 \\
1 \mathrm{~b} \\
\end{array}$ & $217.3 \mathrm{~b}$ \\
\hline 2 & $\begin{array}{c}\text { Giza } \\
171 \\
\end{array}$ & $\begin{array}{c}101.6 \\
\mathrm{a}\end{array}$ & $143.2 \mathrm{c}$ & $\begin{array}{c}113.2 \\
\mathrm{a}\end{array}$ & 2.00 & $617.0 \mathrm{a}$ & $295.0 \mathrm{c}$ & $59.4 \mathrm{a}$ & $\begin{array}{c}54.12 \\
\mathrm{a}\end{array}$ & $\begin{array}{c}10 \mathrm{M} \\
\mathrm{S}\end{array}$ & $\begin{array}{c}0.00 \\
6 \mathrm{~b} \\
\end{array}$ & $166.0 \mathrm{~b}$ \\
\hline 3 & Sids 12 & $98.6 \mathrm{c}$ & $140.0 \mathrm{~d}$ & $\begin{array}{c}110.0 \\
b\end{array}$ & 1.826 & $583.0 \mathrm{a}$ & $306.2 \mathrm{bc}$ & $52.6 \mathrm{~b}$ & $\begin{array}{c}48.99 \\
b\end{array}$ & $70 \mathrm{~S}$ & $\begin{array}{c}0.65 \\
2 \mathrm{a}\end{array}$ & $865.0 \mathrm{a}$ \\
\hline 4 & Sids 13 & $100.0 \mathrm{~b}$ & $146.4 \mathrm{~b}$ & $\begin{array}{c}101.6 \\
\mathrm{c}\end{array}$ & 1.588 & $466.8 \mathrm{~b}$ & $378.8 \mathrm{a}$ & $48.0 \mathrm{c}$ & $\begin{array}{c}36.13 \\
\mathrm{c}\end{array}$ & $5 \mathrm{~S}$ & $\begin{array}{c}0.00 \\
4 \mathrm{~b}\end{array}$ & $123.0 \mathrm{~b}$ \\
\hline & S.D. & 0.726 & 1.109 & 1.961 & n.s & 37.390 & 11.935 & 4.051 & 4.147 & & $\begin{array}{c}0.07 \\
2\end{array}$ & 134.92 \\
\hline
\end{tabular}

1= (FRS) Final rust severity

$2=($ r-value) Rate of yellow rust increase

3= (AUDPC) Area under disease progress curve

The letters a,b,c,d according to Duncan's multiple range test, means followed by a same letter are not significantly different and (n.s) is Non Significantat $5 \%$ probability level 
Table 3. The Morphological character Yield components and disease incidence in four Egyptian bred wheat cultivars at Naboria Agriculture research station during growing season 2016/2017.

\begin{tabular}{|c|c|c|c|c|c|c|c|c|c|c|c|c|}
\hline \multirow[b]{2}{*}{$\begin{array}{c}\text { No } \\
\text {. }\end{array}$} & \multirow[b]{2}{*}{$\begin{array}{c}\text { cultiva } \\
\mathbf{r}\end{array}$} & \multicolumn{3}{|c|}{ Morphological character } & \multicolumn{5}{|c|}{ Yield components } & \multicolumn{3}{|c|}{ Disease incidence } \\
\hline & & $\begin{array}{c}\text { Days of } \\
\text { headin } \\
\quad \mathrm{g}\end{array}$ & $\begin{array}{c}\text { Days of } \\
\text { maturit } \\
y\end{array}$ & $\begin{array}{l}\text { Plant } \\
\text { heigh } \\
t(\mathrm{~cm})\end{array}$ & $\begin{array}{c}\text { Biologica } \\
\text { l yield } \\
\text { (Kg) }\end{array}$ & $\begin{array}{c}\text { Grain } \\
\text { Yield } \\
(\mathrm{kg})\end{array}$ & $\begin{array}{c}\text { N.of } \\
\underset{2}{\text { Spikes/M }}\end{array}$ & $\begin{array}{l}\text { N.of } \\
\text { grain } \\
\text { /spik } \\
\text { e }\end{array}$ & $\begin{array}{c}1000 \\
\text { grain } \\
\text { weigh } \\
t\end{array}$ & $\begin{array}{c}1 \\
\text { FR } \\
\text { S }\end{array}$ & $\begin{array}{c}2 \\
\text { r- } \\
\text { value }\end{array}$ & $\begin{array}{c}3 \\
\text { AUDP } \\
\mathbf{C}\end{array}$ \\
\hline 1 & $\begin{array}{c}\text { Giza } \\
168 \\
\end{array}$ & $102.4 \mathrm{~b}$ & $157.4 \mathrm{a}$ & $\begin{array}{c}109.4 \\
\text { bc }\end{array}$ & $1.88 \mathrm{ab}$ & $\begin{array}{c}550.0 \\
\mathrm{~b}\end{array}$ & 315.0 & $39.0 \mathrm{c}$ & $\begin{array}{c}49.68 \\
b\end{array}$ & $50 \mathrm{~S}$ & 0.031 & $565.0 \mathrm{~b}$ \\
\hline 2 & $\begin{array}{c}\text { Giza } \\
171\end{array}$ & $105.6 \mathrm{a}$ & $157.0 \mathrm{a}$ & $\begin{array}{c}117.8 \\
\mathrm{a}\end{array}$ & $1.96 \mathrm{a}$ & $\begin{array}{c}630.0 \\
\mathrm{a}\end{array}$ & 296.0 & $54.0 \mathrm{a}$ & $\begin{array}{c}57.00 \\
\mathrm{a}\end{array}$ & $20 \mathrm{~S}$ & 0.024 & $292.0 \mathrm{c}$ \\
\hline 3 & Sids 12 & $\begin{array}{c}101.6 \\
b c\end{array}$ & $149.0 \mathrm{~b}$ & $\begin{array}{c}106.4 \\
\text { c }\end{array}$ & $1.59 \mathrm{c}$ & $\begin{array}{c}515.0 \\
\mathrm{~b}\end{array}$ & 305.0 & $\begin{array}{c}45.0 \\
\mathrm{~b}\end{array}$ & $\begin{array}{c}49.61 \\
\text { b }\end{array}$ & $80 \mathrm{~S}$ & 0.846 & $1425.0 \mathrm{a}$ \\
\hline 4 & Sids 13 & $101.0 \mathrm{c}$ & $157.0 \mathrm{a}$ & $\begin{array}{c}111.8 \\
\mathrm{bc}\end{array}$ & $1.60 \mathrm{bc}$ & $\begin{array}{c}515.0 \\
b \\
\end{array}$ & 344.0 & $\begin{array}{c}45.2 \\
\mathrm{~b} \\
\end{array}$ & $\begin{array}{c}35.21 \\
\mathrm{c} \\
\end{array}$ & $10 \mathrm{~S}$ & 0.019 & $130.0 \mathrm{~d}$ \\
\hline & at $5 \%$ & 0.876 & 0.613 & 3.556 & 0.285 & $\begin{array}{c}51.10 \\
0\end{array}$ & n.s & 5.928 & 4.543 & & 0.061 & 107.120 \\
\hline
\end{tabular}

1= (FRS) Final rust severity

$2=(\mathbf{r}$-value $)$ Rate of yellow rust increase

3= (AUDPC) Area under disease progress curve

The letters a,b,c,d according to Duncan's multiple range test, means followed by a same letter are not significantly different and (n.s) is Non Significantat 5\% probability level

Polymorphism as detected by ISSR analysis:

ISSR (inter-simple sequence repeat) marker was used to measure the genetic diversity between one yellow rust resistant wheat cultivar (YR7), the four local cultivated varieties and the F1 cross progeny. These ISSR primers produced good reproducible and scorable patterns and the amplification profiles were screened for the presence of polymorphism (Fig.1). As shown in Table (4) Ten ISSR primers were used, a total of 109 bands were amplified with an average of
10.9 bands. The number of fragment per primer ranged from 6 to 14, while the number of polymorphic amplicons varied from 2 to 8 and the average level of polymorphism was $37 \%$. Primer ISSR- 8 yielded the highest number of products (14 amplicons), while primers ISSR-3 detected the lowest number (6 amplicon). The average number of polymorphic amplicon/primer among the wheat cultivars was 4.1. Moreover, the size of the amplified alleles varied with different primers, ranging from 130 to $2500 \mathrm{bp}$.

Table 4. Primer, Sequence, (TM) Total number of amplicons, (MP) monomorphic amplicons, (PP) polymorphic amplicons and $(\% \mathrm{P})$ percentage and Frequency of polymorphism as revealed by ISSR markers among the wheat cultivars.

\begin{tabular}{ccccccc}
\hline Primer & Sequence5 - 3 & TM & MP & PP & \% P & Frequency \\
\hline ISSR-1 & AGAGAGAGAGAGAGAGYC & 10 & 8 & 2 & 20 & 0.9 \\
\hline ISSR-2 & AGAGAGAGAGAGAGAGYG & 9 & 7 & 2 & 22 & 0.9 \\
\hline ISSR-3 & ACACACACACACACACYT & 6 & 4 & 2 & 33 & 0.8 \\
\hline ISSR-4 & ACACACACACACACACYG & 10 & 7 & 3 & 30 & 0.9 \\
\hline ISSR-5 & GTGTGTGTGTGTGTGTYG & 12 & 7 & 5 & 42 & 0.7 \\
\hline ISSR-8 & AGACAGACAGACAGACGC & 14 & 6 & 8 & 57 & 0.8 \\
\hline ISSR-10 & GACAGACAGACAGACAAT & 11 & 9 & 2 & 18 & 0.9 \\
\hline ISSR-11 & ACACACACACACACACYA & 12 & 8 & 4 & 33 & 0.8 \\
\hline ISSR-12 & ACACACACACACACACYC & 12 & 7 & 5 & 42 & 0.8 \\
\hline ISSR-14 & CTCCTCCTCCTCCTCTT & 13 & 5 & 8 & 80 & 0.7 \\
\hline Total & & $\mathbf{1 0 9}$ & $\mathbf{6 8}$ & $\mathbf{4 1}$ & & $\mathbf{8 . 2}$ \\
\hline Average & & $\mathbf{1 0 . 9}$ & $\mathbf{6 . 8}$ & $\mathbf{4 . 1}$ & $\mathbf{3 7}$ & $\mathbf{0 . 8}$ \\
\hline
\end{tabular}



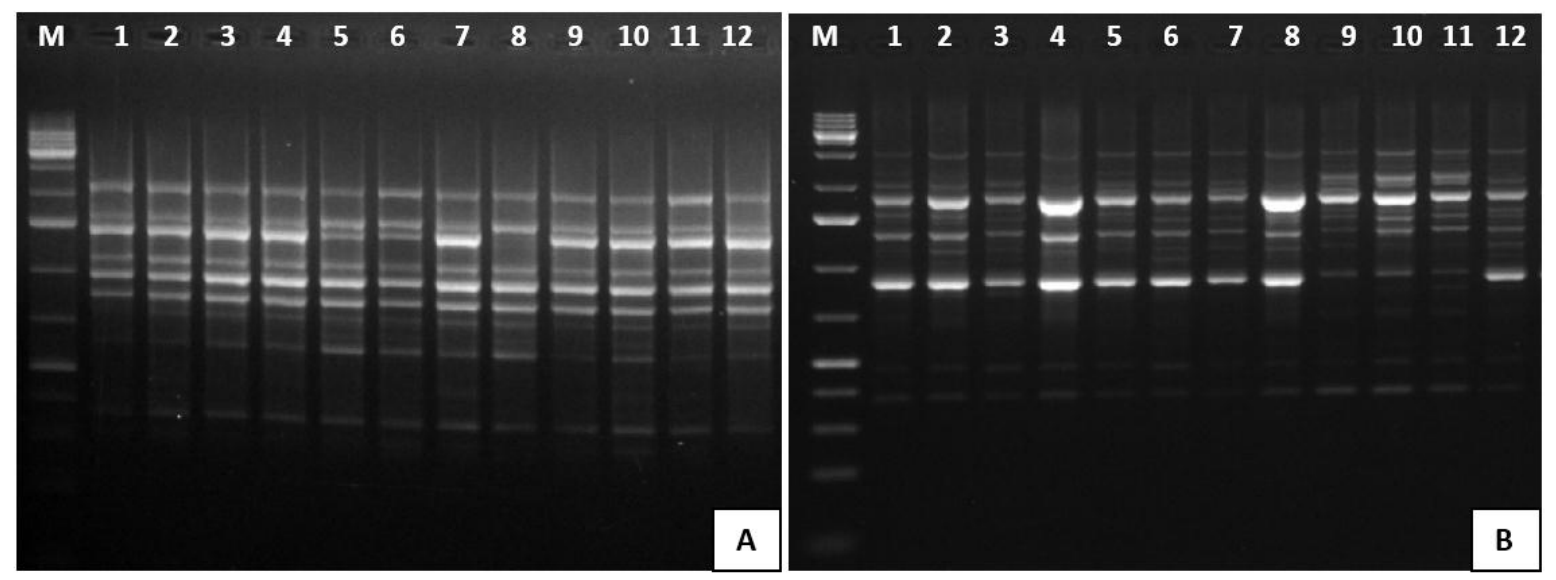

Fig 1. ISSR profiles of the 12 cultivar as revealed by primers ISSR-12(A) and ISSR-8 (B). Lanes 1 to 12

represent: 1- Yr7, 2- F1(Yr7*SD12), 3- SD12, 4- Yr7, 5- F1 (Yr7*SD13), 6- SD13, 7- Yr7 , 8- F1 (Yr7*G168), 9- G168, 10- Yr7 , 11- F1 (Yr7*G171) and 12- G171. M: DNA molecular weight marker (1kb Ladder).

\section{Genetic relationships phylogenetic tree revealed by ISSR markers:}

The Dice coefficient genetic similarity ranged from $88 \%$ between SD12, Yr7 and F1 (Yr7*G168) and between SD13 and F1 (Yr7*G168). On the other hand, SD13 and F1 (Yr7*SD13) gave the highest genetic similarity (96\%) and between G168 and F1 (Yr7*G168) and between F1 (Yr7*G171) and G171.

Table 5. Genetic similarity of wheat accession using ISSR data as revealed by Dice coefficient.

Matrices of similarities between pairs of individuals may be used as a starting point for statistical procedures

\begin{tabular}{|c|c|c|c|c|c|c|c|c|c|}
\hline & Yr7 & F1(Yr7*SD12) & SD12 & F1(Yr7*SD13) & SD13 & $\mathrm{F} 1\left(\mathrm{Yr} 7{ }^{*} \mathrm{G} 168\right)$ & G168 & F1(Yr7*G171) & G171 \\
\hline Yr7 & $100 \%$ & & & & & & & & \\
\hline F1(Yr7*SD12) & $92 \%$ & $100 \%$ & & & & & & & \\
\hline SD12 & $88 \%$ & $94 \%$ & $100 \%$ & & & & & & \\
\hline F1(Yr7*SD13) & $91 \%$ & $93 \%$ & $92 \%$ & $100 \%$ & & & & & \\
\hline SD13 & $90 \%$ & $91 \%$ & $91 \%$ & $96 \%$ & $100 \%$ & & & & \\
\hline $\mathrm{F} 1\left(\mathrm{Yr} 7{ }^{*} \mathrm{G} 168\right)$ & $89 \%$ & $91 \%$ & $88 \%$ & $92 \%$ & $88 \%$ & $100 \%$ & & & \\
\hline G168 & $92 \%$ & $93 \%$ & $90 \%$ & $93 \%$ & $90 \%$ & $96 \%$ & $100 \%$ & & \\
\hline $\mathrm{F} 1\left(\mathrm{Yr} 7^{*} \mathrm{G} 171\right)$ & $95 \%$ & $92 \%$ & $90 \%$ & $93 \%$ & $90 \%$ & $92 \%$ & $96 \%$ & $100 \%$ & \\
\hline G171 & $92 \%$ & $91 \%$ & $91 \%$ & $96 \%$ & $93 \%$ & $92 \%$ & $96 \%$ & $96 \%$ & $100 \%$ \\
\hline
\end{tabular}

such as cluster analysis. In a cluster analysis, relatively homogeneous groups of individuals cluster together in a hierarchical way and this clustering is visually displayed in a dendrogram. Based on the 99 polymorphic SSR alleles generated by the 10 primer pairs, the similarity matrix was developed by analyzing only the common amplified between the different cultivars. A dendrogram (Fig. 2) was constructed using the UPGMA cluster analysis. The phylogenetic tree constructed using the ISSR data was divided into two clusters. The first clusters contains two sub-cluster, one sub-cluster contain F1 $\left(\mathrm{Yr} 7{ }^{*} \mathrm{G} 168\right)$ while the second sub-cluster contain (Yr7, G171, F1 (Yr7*171) and G168). While, the second cluster was divided into two sub-clusters, one sub-cluster contain (F1(Yr7*SD13) and SD13). While, the second sub-cluster contain (F1(Yr7*SD12) and SD12). 


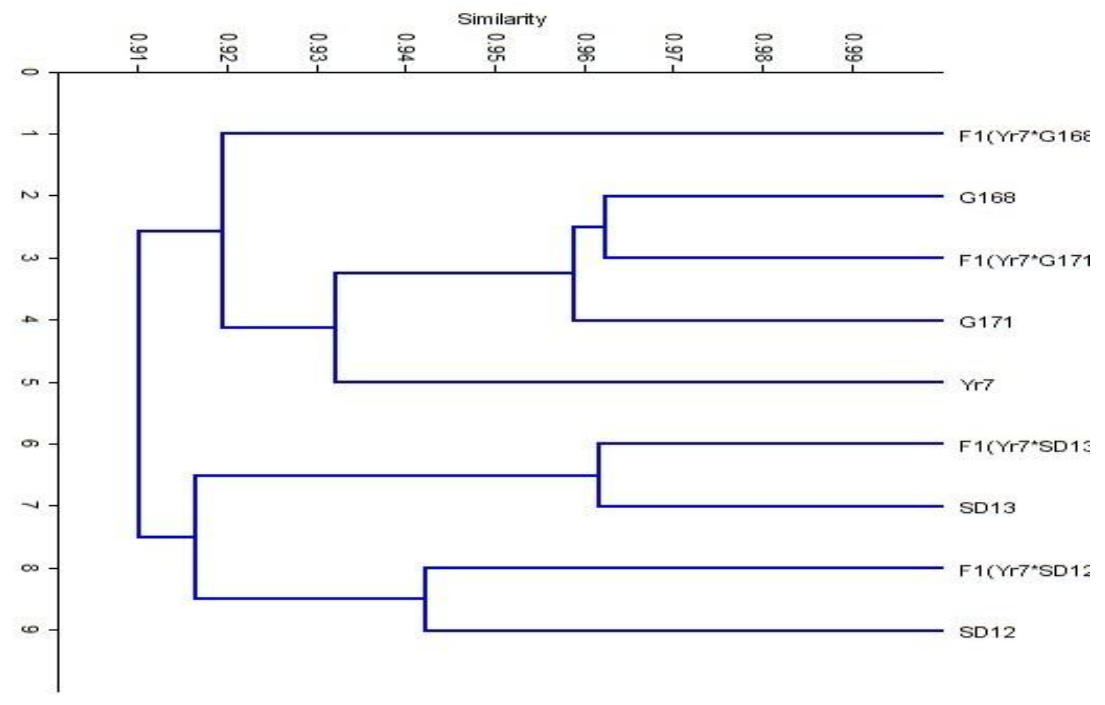

Figure 2: The phylogenetic tree constructing using ISSR data.

\section{Discussion}

\section{Morphological character}

Showed that cultivars Giza 171and Giza 168 recorded the highest significant effects for days to heading, maturity and plant high in both growing seasons. Decreasing rust severity in these cultivars may be caused early heading, maturity and plant high in both seasons. The earliest heading and maturity were recorded for101.6, 143.2 and 98.4,149 days, respectively in the first season and the second season were 105.6, 157 and 102.4,157.4 days, respectively Table (3.,4) The observed significant variation among the cultivars might reflects partially their different genetic backgrounds and environmental conditions such as soil, moisture and good nutrient conditions in increasing the period of vegetative growth and increases the number of days from planting until deadline and physiological mature. These results were agreed with that obtained by Gab Alla (2007), Sharshar (2010), El-hag (2011), Omar et al. (2014). El-hag (2016) and Kandil et al. (2016). Giza 171 produced the tallest plant height of 113.2 and 117.8 $\mathrm{cm}$ in the first and second seasons, respectively, followed by Giza 161110 and 109.4 c, respectively. Increase the number of irrigations, good nutrient conditions and yellow rust resistance cultivars lead to increased nutrition available and thus increase plant growth especially plant height, increasing the size and number of cells between the internodes, which resulting in increasing plant height. These results are agree with those found by; Gab Alla (2007), Shehab El-Din (2008), EL-Shamy (2009), Moayedi et al. (2010). Sharshar (2010), El-hag (2011), Qamar et al. (2013), Zafarnaderi \& Mohammadi (2013) and Omar et al. (2014). The differences between cultivars are often due to genetic makeup as well as the interaction between genetic makeup and environmental conditions. Omar et al. (2014), El-hag (2016) and Kandil et al. (2016) were recorded the same findings.

\section{Yield components:}

Indicated that the differences among the four cultivars were significant for, Grain Yield kg, number .of grain /spike and 1000 grain weight. Giza 171 recorded the highest number of grain yield $\mathrm{kg}$, number .of grain /spike and 1000 grain weight $(617 \mathrm{~kg}, 59.4$ grain and $54.12 \mathrm{gm})$ in first season and $(630 \mathrm{~kg}, 54$ grain and $57 \mathrm{gm}$ ) in second season respectively, compared to Giza 168 had the lowest number of number of grain /spike t (46.6 and 39 grain/spike) in two season respectively, and also sids 13 had the lowest number of 1000 grain weigh gm (36 13 and $35.21 \mathrm{gm})$ in two season respectively Table $(2,3)$. Increase the availability of moisture and nutrients from the soil to plant lead to increased vegetative growth and thereby increase the metabolic rate and thus storage in grain, thus resulted increasing grain weight. These results are in agreement with those reported by Moayedi et al. (2010), Sharshar (2010), Akbari et al. (2011), Al Tahar et al. (2011), El-hag (2011), Mojtaba et al. (2013), Qamar et al. (2013), Zafarnaderi \& Mohammadi (2013) and Omar et al. (2014). Grain weight of the most important characteristics of varieties and feedback to genotype gene. Spikelet number determined in the vegetative stage of growth, especially after the tillering stage and until the date of heading the greater availability of 
appropriate conditions for growth especially moisture and nutrients is increasing the number of grains/spike,. These results are partially in line with those reported by Moayedi et al. (2010). Sharshar (2010), Akbari et al. (2011), Al Tahar et al. (2011), El-hag (2011) Mojtaba et al. (2013), Qamar et al. (2013), Zafarnaderi \& Mohammadi (2013), Omar et al. (2014). Reduction in photosynthesis and translocation of reserves to grains lead to decrease the grain yield due to (Fisher \& Maurer, 1978 and Keim \& Kronstad, 1981). Similar results were obtained by Abdelraouf et al. (2013), Attia \& Barsoum (2013), Ghanbari \& Tavassoli (2013), Mojtaba et al. (2013), Ngwako \& Mashiqa (2013) and Qamar et al. (2013).

While Biological yield $(\mathrm{Kg})$ was non-significant in first season but in second season was highly significant in cultivars Giza 171 that had the highest number of Biological yield $(\mathrm{Kg}) 1.96 \mathrm{~kg}$ that were. as a result of the availability of soil moisture and thus the necessary nutrients for plants during the growing season to increase the yield components in addition to increase Biological yield $(\mathrm{Kg})$. These results are in agreement with those reported by Gab Alla (2007), Shehab El-Din (2008), EL-Shamy (2009), Sharshar (2010), El-hag (2011), Mojtaba et al. (2013), Qamar et al., (2013), Zafarnaderi \& Mohammadi (2013) and Omar et al. (2014). and also in the second season number of spike $/ \mathrm{m}^{2}$ was non significant but in first season was highly significant in cultivars Sids 13 that had the highest number of spike/ $\mathrm{m}^{2}$ (378.8 spike/m² ) compared to Giza 171 which had the lowest number of spike/m2 (295 spike/m2). We well known that the tillers is initiated in the first stage of growth, but the number of fertile tillers (spike) is controlled by the availability of nutrients and moisture in the following stages and this was clear from the results of the experiment means which indicated that the number of spikes per unit area is gradually increased with increasing number of irrigations, good nutrient conditions and disease free These results are in agreement with those reported by Moayedi et al. (2010), Sharshar (2010), Akbari et al. (2011), Al Tahar et al. (2011), El-hag (2011), Mojtaba et al. (2013), Qamar et al. (2013), Zafarnaderi \& Mohammadi (2013) and Omar et al. (2014).

\section{Disease assessment}

The field observations indicated that more yellow rust epidemic was recorded in the second growing season 2016/2017 than in the first one. The data observations indicated that the most yellow rust epidemic was recorded in cultivars Sids 12 in the two season Table $(2,3)$ Where had the highest values of final rust severity (70S and $80 \mathrm{~S}$ ), rate of disease increase (0.652 and 0.846)and area under disease progress curve( 865 and 1425) compared to Sids 13 that had the lowest values of final rust severity $(5 \mathrm{~S}$ and $10 \mathrm{~S})$, rate of disease increase $(0.004$ and 0.019 )and area under disease progress curve( 123 and
130), respectively. Studies carried out under the Egyptian field conditions by Nazim et al. (1990); Negm (2004); Boulot (2007) and Boulot and Ali (2014a) were in accordance with the results obtained in this study. Thereby, some of the Egyptian wheat cultivars have an adequate level of field resistance to yellow rust and many of these cultivars severed in agriculture for many years, showing high level of partial resistance during their vast cultivations under Egyptian field conditions. Boulot and Ali (2014a) reported that the expression of partial resistance was slightly affected by the changes in environmental conditions from one year to another. Hence, the expression of this type of resistance remains stable under various environmental conditions favorable to the pathogen infection. The effect of yellow rust infection on grain yield of wheat cultivars may be due to affecting the photosynthetic area of the top three leaves especially flag leaf, which shares with its sheath by about 75 percentages in determining the grain weight, while the ear shares by only 25 percent. Grain shrivels and nutrients produced primarily in the flag leaf are used by the fungus rather than transported to the grain (Buchenau, 1975; Johnston, 1931; Seck et al., 1988 and subba Rao et al., 1989)

\section{ISSR Marker}

In this study, cultivars Yr7*SD13 and Yr7*SD12 were clustered in one branch with their ancestors SD13 and SD12 with a genetic similarity of $96 \%$ and $94 \%$, respectively. This indicates that, ISSR analysis was successful to track these local cultivars progeny. On the other hand, cultivars Giza 168 and Yr7*G168 were separated which could suggest that the genetic impact of Yr7 with higher than Giza168. The high yield cultivars Giza 171 and Giza 168 were the highest similar to Yr7 with a genetic similarity of $92 \%$, while SD12 and SD13 generated $88 \%$ and $90 \%$ of genetic similarity with Yr7, respectively. In this regard, Abou-Deif et al. (2013) analyzed of 20 wheat genotyping using ISSR inter-simple sequence repeat marker. Eight ISSR primers produced 112 amplified ranges from $1231850 \mathrm{bp} .17$ fragment were monomorphic $(15 \%)$ and 95 fragments were polymorphic $(85 \%)$ with average of 11.8 polymorphic per primer. While, Sofalian et al., (2009) used Intersimple sequence repeat (ISSR) markers were to determine the genetic diversity of 39 bread wheat accessions, including 33 wheat landraces and 6 wheat cultivars from northwest of Iran. Out of 129 amplified scored bands, 106 (82.2\%) were polymorphic. Average of amplified and polymorphic bands per primer was calculated as 11.7 and 9.6, respectively.

\section{References}

Abou-Deif, M.H.; Rashed,M.A.; Sallam, M.A.A.; Mostafa, E.A.H.; and Ramadan, W.A.(2013). Characterization of Twenty Wheat Varieties by 
ISSR Markers. Middle-East Journal of Scientific Research 15 (2): 168-175

Abu El-Naga, S. A.; M. M. Khalifa, S.Sherif; W. A.Youssef,; Y. H. El-Daoudi, and I.Shafik, (2001), Virulence of wheat stripe rust pathotypes identified in Egypt during 1999/2000 and sources of resistance. First Regional Yellow Rust Conference for Central \& West Asia and North Africa 8-14 May, SPH, Karj, Iran. 15(2): 79-84.

Akbari, M. H., Galavi, M., Fanaei, H.R., Koohkan, S.H.A. and Poodineh, O. (2011)Effects of deficit irrigation on grain yield and some morphological traits of wheat cultivars in drought - prone conditions. International Journal of Agri. Sci. 1(4), 249-257.

Al Tahar, B., El Hwary, A. and Yagoub, S. O. (2011) Effect of skipping irrigation on growth, yield, yield components and water use efficiency of wheat (Triticum aestivum L.) in semi arid Region of Sudan. Agric. Biol. J. N. 2(6), 10031009.

Al-Kaab, D.H., Hamdalla, M.S., Dweikat, I.M. and Al-Saedi, N.J., (2016). Estimation of the Degree of Diversity for Some Iraqi Wheat Varieties through ISSR, SRAP and RAPD Markers.

AmmiRaju, J.S.S., Dholakia, B.B., Santra, D.K., Singh, H., Lagu, M.D., Tamhankar, S.A., Dhaliwal, H.S., Rao, V.S. Gupta, and P.K. Ranjekar (2001). Identification of inter-simple sequence repeat (ISSR) markers associated with seed size in wheat. Theor. Appl. Genet. 102: 726732.

Boulot, O.A. (2007). Durable resistance for leaf rust in twelve Egyptian wheat varieties. Egypt. J. Appl. Sci., 22(7): 40-60.

Boulot, O.A. and ALY, A.A. (2014). Partial resistance of wheat (Triticum astivum) to leaf rust (Puccinia triticina) in Egypt. Egypt. J. Agric. Res., 92(3): 835-850.

Das, M.K.; Rajaram, S.; Ktonstad, W.K.; Mundt, C.C. and Singh, R.P. (1993). Association and genetics of three components of slow rusting in leaf rust of wheat. Euphytica, 68: 99-109.

Duncan, D. B. (1955). Multiple range and multiple F tests. Biometrics li, 1-42.

El hag, Dalia A. A. (2016) Effect of seeding rates on yield and yield components of two bread wheat cultivars. J. Agric. Res. Kafr El-Sheikh Univ. J. Plant Production, 42(1), 29-43.

El hag, Walaa A. A. (2011) Evaluation of some cultivars and lines of bread wheat under low input. M.Sc.Thesis, Kafrelsheikh Univ., Egypt.

El-Beltagy, A.T. and Abo-Hadeed, A.F. (2008) The main pillars of the National Program for maximizing the water-use efficiency in the old land. The Research and Development Council. MOALR. (in Arabic); p. 30.

El-Shamy, A. E. A. (2009) .Evaluation of some wheat hybrids for drought tolerance. M.Sc. Thesis, Kafrelsheikh Univ., Egypt.
Fisher, R.A. and Maurer, R. (1978) Drought resistance in spring wheat cultivars. I. Grain yield responses. Asut. J. Agric. Res. 29, 897-912.

Gab Alla, M.M. (2007) Effect of irrigation numbers on some varieties and strains of wheat M.Sc. Thesis, Kafrelsheikh Univ., Egypt.

Ghanbari, A. and Tavassoli, A. (2013) Evaluation of wheat yield in water and nitrogen limited condition. Tech J Engin \& App Sci. 3 (20), 27022705.

Goyal, M., Kumar, P. and Dhillon, S. (2015). Molecular Marker analysis Reveals Genetic Diversity among Wheat (Triticum aestivum L. em. Thell) Genotypes varying for ThermoTolerance. Vegetos-An International Journal of Plant Research, 28(4), pp.54-61.

Johnson R, (1992). Past, present and future opportunities in breeding for disease resistance, with examples from wheat. Euphytica 63:3-22.

Johnson, D. W., \& Johnson, R. (1992). Interaction in cooperative groups: The theoretical anatomy of group learning. New York: Cambridge University Press.

Kandil, A. A., Sharief, A. E.M., Seadh, S.E. and Altai,. D. S. K (2016) Role of humic acid and amino acids in limiting loss of nitrogen fertilizer and increasing productivity of some wheat cultivars grown under newly reclaimed sandy soil. Int. J. Adv. Res. Biol. Sci. 3(4), 123-136

Karrou, M. , Oweis, T., Abou El Enein, R. and Sheri, M. (2012) Yield and water productivity of maize and wheat under deficit and raised bed irrigation practices in Egypt. African Journal of Agricultural Research, 7, 1755-1760.

Keim, D.L. and Kronstad, W. E. (1981) Stress response of winter wheat cultivars grown under field stress condition. Crop Sci. 21,11-15.

Kojima, T., Nagaonka, T., Noka, K., Ogijhara, Y. (1998). Genetic linkage map of ISSR and RAPD markers in Einkorn wheat in relation to that of RFLP markers. Theor. Appl. Genet. 96: 37-45.

Moayedi, A. A., Boyce, A. N. and Barakbah, S. S. (2010) The performance of durum and bread wheat cultivars associated with yield and yield component under different water deficit conditions. Australian Journal of Basic and Applied Sciences, 4(1), 106-113.

Nagaoka, T., Ogihara, Y. (1997). Applicability of inter-simple sequence repeatpolymorphisms in wheat for use as DNA markers in comparison to RFLP and RAPD markers. Theor. Appl. Genet. 94: 597-602.

Nazim, M.S.; El-Shanawani, M.Z. and Boulot, O.A. (1990). Partial resistance to leaf rust in some Egyptian wheat cultivars. Proc. Of the 6th Congress of the Egyptian Phytopathology Society Part 1, pp 77-97.

Negm, S.S. (2004). Partial Resistance to Leaf Rust in Some Egyptian Wheat Varieties. Ph.D. Thesis, Fac. Agric., Minufiya Univ., 180p. 
Omar, A. M., Mohamed, A. A. E., Sharsher, M. S. A ., El-hag, Walaa.A.A. (2014) Performance of some bread wheat genotypes under water regime and sowing methods. J. Agric. Res. Kafrelsheikh Univ. 40 (2),327-341.

Pandey, H.N.; Menon, T.C.M. and Rao, M.V. (1989). A simple formula for calculating area under disease progress curve. Rachis, 8(2): 38-39.

Pratt, R.C., and S.G. Gordon. (2006). Breeding for resistance to maize foliar pathogens. Plant Breed. Rev. 27:119-173.

Roelfs, A.P. and Bushnell, W.R. (1985). The Cereal Rusts. Aca- demic Press, Orlando, FL.

Seck, M.; Roelfs, A.P. and Teng, P.S. (1988). Effect of leaf rust (Puccinia recondita tritici) on yield of four isogenic lines. Crop Protection, 7: 39-42.

Sharshar, A. M. (2010) combining ability and heterosis for bread wheat under stress and normal irrigation numbers. M.Sc. Thesis, Kafrelsheikh Univ.

Shehab El-Din, M.T.E. (2008) Breading studies on earliness and drought tolerance in bread wheat.M.Sc.Thesis, Cairo Univ., Egypt.

Singh R.P., Rajaram S., Huerta-Espino J., William H.M. (2004): Durable resistance to yellow (Stripe) rust in wheat. Available at www.cimmyt.org/research/wheat/map/research_r esults/reshighlights/pdfs/resigh_durabresist.pdf
Singh RP, H.M. William, J. Huerto-Espino and G. Rosewarne, (2004). Wheat rust in Asia: Meeting the challenges with old and new technologies. Proceedings of the 4th International Crop Science Congress, 26 Sep.-1 Oct. 2004, Brisbane, Australia.

Sofalian, O. Chaparzadeh, N. and Dolati, M. (2009). Genetic Diversity in Spring Wheat Landraces from Northwest of Iran Assessed by ISSR Markers. Not. Bot. Hort. Agrobot. Cluj 37 (2), 252-256

Subba, Rao, K.V.; Yang, X.B.; Berggren, G.T. and Snow, J.P. (1989). A multiple regression model to estimate the contributions of leaves and the effects of leaf rust on yield of winter wheat Phytopathology, 79: 1233-1238.

Van der Plank, T.E. (1963). Plant diseases. Epidemics and control. Academic Press.New York, pp. 349.

www.cimmyt.org/research/wheat/map/research results/ reshighlights/pdfs/resigh_durabresist.pdf

Zafarnaderi, N. S. A. and Mohammadi, S. A. (2013) Relationship between grain yield and related agronomic traits in bread wheat recombinant inbred lines under water deficit condition An

Zietkiewicz E, Rafalski A, Labuda D (1994) Genome fingerprinting by simple sequence repeat (SSR)-anchored polymerase chain reaction amplification. Genomics 20: 176-183. 
